\title{
Peridomiciliary colonies of Triatoma vitticeps (Stal, 1859) (Hemiptera, Reduviidae, Triatominae) infected with Trypanosoma cruzi in rural areas of the state of Espírito Santo, Brazil
}

\section{Claudiney Biral dos Santos/ ${ }^{+}$, Adelson Luiz Ferreira*, Gustavo Rocha Leite*, Gabriel Eduardo Melim Ferreira*, Andressa Alencastre Fuzari Rodrigues*, Aloísio Falqueto}

\author{
Unidade de Medicina Tropical, Universidade Federal do Espírito Santo, Av. Marechal Campos 1468, 29040-090 Vitória, ES, \\ Brasil *Núcleo de Entomologia, Funasa/Sesa/ES, Vitória, ES, Brasil
}

In Brazil, the colonization of human dwellings by triatomines occurs in areas with native vegetation of the caatinga or cerrado types. In areas of Atlantic forest such as in the Brazilian state of Espirito Santo, there are no species adapted to live in human habitations. The few autochthonous cases of Chagas disease encountered in Espírito Santo have been attributed to adult specimens of Triatoma vitticeps that invade houses from forest remnants. In recent years, the entomology unit of the Espirito Santo State Health Secretariat has recorded nymphs infected with flagellates similar to Trypanosoma cruzi in rural localities. Entomological surveys were carried out in the residences and outbuildings in which the insects were found, and serological examinations for Chagas disease performed on the inhabitants. Four colonies were found, all associated with nests of opossums (Didelphis aurita), 111 specimens of T. vitticeps, and 159 eggs being collected. All the triatomines presented flagellates in their frass. Mice inoculated with the faeces presented trypomastigotes in the circulating blood and groups of amastigotes in the cardiac muscle fibres. Serological tests performed on the inhabitants were negative for T. cruzi. Even with the intense devastation of the forest in Espirito Santo, there are no indications of change in the sylvatic habits of $\mathrm{T}$. vitticeps. Colonies of this insect associated with opossum nests would indicate an expansion of the sylvatic environment into the peridomicile.

Key words: Triatoma vitticeps - peridomiciliary colonies - Trypanosoma cruzi - Espírito Santo - Brazil

At least five of the 125 species of triatomines recorded in the Americas have acquired the capacity to colonize human dwellings (Galvão et al. 2003). In Brazil, the distribution of triatomines associated with houses coincides with human colonization of areas with natural vegetation of the cerrado or caatinga types. Atlantic forest areas generally do not present foci of domiciliation (Forattini 1980, Coura 2003).

During the 20th century, forests in the Brazilian state of Espírito Santo were devastated for the exploitation of timber and planting of diverse agricultural crops, leaving only $8.15 \%$ of the territory with natural vegetation coverage. The impact of these actions culminated in the extinction of many species and adaptation of others to the new conditions imposed by man (Ipema 2004).

None of the seven triatomine species recorded in Espírito Santo has acquired the capacity of domiciliation (Galvão et al. 2003, Santos et al. 2004). The adult specimens of Triatoma vitticeps (Stal, 1859) that are frequently captured in the domiciliary environment in rural areas are attracted by lights or are seeking bloodmeals (Sessa \& Carias 1986, Dias et al. 1989).

${ }^{+}$Corresponding author. E-mail: claudiney @ ppgcf.ufes.br Received 22 February 2005

Accepted 1st August 2005
Serological surveys have demonstrated a low prevalence of Chagas disease in Espírito Santo, the few autochthonous cases of human transmission being attributed to T. vitticeps (Barros et al. 1975, Sessa et al. 2002), which is also incriminated as a vector of the parasite in the state of Rio de Janeiro (Lorosa et al. 2003).

The objective of the present study was to investigate the significance of the finding of $T$. vitticeps nymphs infected with $T$. cruzi in an anthropic environment of the state of Espírito Santo, Brazil.

In routine entomological vigilance studies carried out in 2002-2004, the entomology unit of the State Health Secretariat recorded $T$. vitticeps nymphs with flagellates similar to $T$. cruzi in the municipalities of Venda Nova do Imigrante $\left(20^{\circ} 24^{\prime}, 14^{\prime \prime} \mathrm{S} ; 41^{\circ} 08^{\prime}, 48^{\prime \prime} \mathrm{W}\right)$ and Castelo (20³2',56'S; 41 02 ', 11'W) (Figure), located at about 800 $\mathrm{m}$ above sea level in the mountainous region of Espírito Santo.

Based on these findings, entomological surveys were carried out in these localities, looking for indicators of domiciliation of this triatomine. An active search for the insects was carried out in residences and outbuildings, domestic animal shelters and timber piles in the peridomicile.

The excreta of the triatomines collected were examined using optical microscopy and those that contained flagellates were inoculated into the peritoneal cavities of mice. Blood samples from these animals were examined 


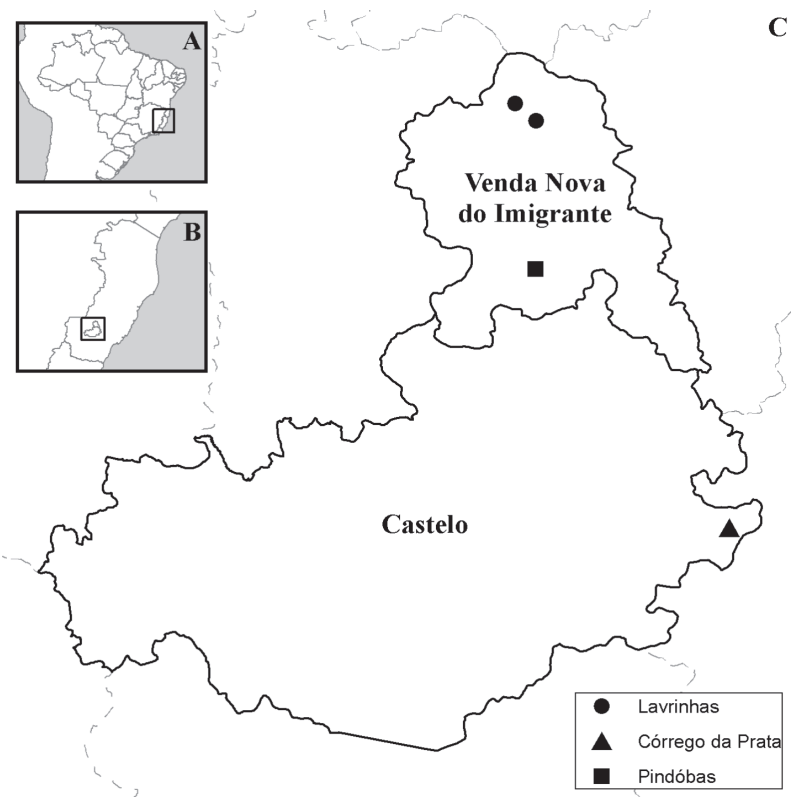

Map of the state of Espírito Santo. A: Brazil; B: state of Espírito Santo; C: municipalities where we found the colonies of Triatoma vitticeps.

from the second week onwards and histological sections of cardiac muscle were obtained from animals with circulating trypomastigotes.

Samples of blood were collected from 18 inhabitants of five residences investigated, for serological detection of $T$. cruzi infection using the ELISA, indirect immunofluorescence, and haemagglutination methods.

One hundred and eleven specimens of $T$. vitticeps, consisting of adults and nymphs of several stages as well as 159 eggs were obtained from investigations of the surroundings of five residences (Table). All the T. vitticeps colonies were associated with nests of opossums (Didelphis aurita).

A colony encountered in Córrego Prata, in the municipality of Castelo, Espírito Santo, was associated with an opossum nest located under the timber pile of an inhabited dwelling. In the remaining localities the colonies were associated with nests located in spacious outbuildings used to store tools and in woodpiles.

All the triatomines collected presented flagellates in their faeces. Inoculations of faecal samples from 13 triatomines in the peritoneal cavities of mice produced acute parasitaemia, with numerous trypomastigotes in the blood and groups of amastigotes in the cardiac muscle fibres. Serological tests for Chagas disease were negative in all the inhabitants examined.

The triatomine $T$. vitticeps is considered to be a poor vector of T. cruzi, because of its sylvatic habits and probably also because it does not defecate during or immediately after a bloodmeal (Gonçalves et al. 1988). The rare human cases of Chagas disease in Espírito Santo would be consequences of the occasional incursion in the domiciliary environment by wild triatomines. Nymphs are rarely found and are generally not infected. These nymphs are probably descended from wild females, which not tend to colonize human dwellings (Sessa \& Carias 1986). However, intense destruction of the forest could induce changes in the habits of $T$. vitticeps, as already observed in other species.

In the state of Rio de Janeiro, Lorosa et al. (2004) reported domiciliated $T$. vitticeps infected with $T$. cruzi. However these authors did not investigate the possible co-existence of the triatomines with wild animals.

Based on the results of the present study, there do not appear to be indices of change in the behaviour of this species. Opossum nests with which the triatomine colonies are associated represent an expansion of the sylvatic environment into the peridomicile. Nevertheless, given the frequency with which opossums approach rural residences, entomological vigilance is necessary to ensure that infected $T$. vitticeps colonies do not become established in the peridomiciliary areas of houses.

\section{REFERENCES}

Barros GC, Mayrink W, Salgado AA, Barros RCG, Sessa PA 1975. Contribuição para o conhecimento da doença de Chagas autóctone no estado do Espírito Santo. Rev Inst Med Trop São Paulo 17: 319-329.

Coura JR 2003. Tripanossomose, doença de Chagas. Rev Ci Cult 55: 30-33.

Dias JCP, Feitosa VR, Ferraz Filho AN, Rodrigues VLC, Alencar SA, Sessa PA 1989. Fonte alimentar e potencial vetorial de Triatoma vitticeps (Stal, 1859) com relação à doença de Chagas humana no estado do Espírito Santo, Brasil (Hemiptera, Reduviidae). Mem Inst Oswaldo Cruz 84: 165-173.

Forattini OP 1980. Biogeografia, origem e distribuição da domiciliação de triatomíneos no Brasil. Rev Saúde Pública 14: 265-299.

TABLE

Developmental stage compositions of Triatoma vitticeps colonies found in rural areas of the state of Espírito Santo, Brazil - 2002-2004

\begin{tabular}{lcrrrrrrr}
\hline & \multicolumn{7}{c}{ Nymphs (stages) } & \\
\cline { 3 - 6 } Municipality (locality) & Eggs & 1st & 2nd & 3rd & 4th & 5th & Adult & Total \\
\hline Venda Nova do Imigrante (Pindobas) & 146 & - & 7 & 6 & 17 & 2 & 14 & 46 \\
Venda Nova do Imigrante (Lavrinhas) & - & 1 & 3 & 10 & 8 & 7 & 2 & 31 \\
Castelo (Córrego Prata) & - & - & 1 & 2 & 1 & 2 & 3 & 9 \\
Venda Nova do Imigrante (Lavrinhas) & 13 & 3 & 12 & 13 & 9 & 5 & 3 & 45 \\
\hline Total & 159 & 4 & 23 & 31 & 35 & 16 & 22 & 111 \\
\hline
\end{tabular}


Galvão C, Carcavallo R, Rocha DS, Jurberg J 2003. A checklist of the current valid species of the subfamily Triatominae Jeannel, 1909 (Hemiptera Reduviidae) and their geographical distribution, with nomenclatural and taxonomic notes. Zootaxa 202: 1-36.

Gonçalves TCM, Victório VMN, Jurberg J, Cunha V 1988. Biologia do Triatoma vitticeps (Stal, 1959) em condições de laboratório (Hemiptera: Reduviidae: Triatominae). I Ciclo evolutivo. Mem Inst Oswaldo Cruz 83: 519-523.

Ipema-Instituto de Pesquisas da Mata Atlântica 2004. Conservação da Mata Atlântica no Estado do Espírito Santo: Cobertura Florestal, Unidades de Conservação e Fauna Ameaçada (Programa Centros para a Conservação da Biodiversidade - Conservação Internacional do Brasil), Ipema, Vitória, $112 \mathrm{pp}$.
Lorosa ES, Valente MVMP, Cunha V, Lent H, Jurberg J 2003. Foco de doença de Chagas em Arcádia, estado do Rio de Janeiro, Brasil. Mem Inst Oswaldo Cruz 98: 885-887.

Santos CB, Rangel CV, Leite GR 2004. Ocorrência de Panstrongylus diasi Pinto \& Lent, 1946 (Hemiptera, Reduviidae, Triatominae) no estado do Espírito Santo, Brasil. Entomol Vect 11: 363-367.

Sessa PA, Carias VRD 1986. Infecção natural de triatomíneos do Espírito Santo por flagelados morfologicamente semelhantes ao Trypanosoma cruzi. Rev Soc Bras Med Trop 19: 99-100.

Sessa PA, Pimentel RR, Ferreira AL, Falqueto A 2002. Soroprevalência da doença de Chagas em crianças em idade escolar do estado do Espírito Santo, Brasil, 1999-2000. Cad Saúde Pública 18: 1765-1769. 